\title{
Long term effects of maternal protein restriction on postnatal lung alveoli development of rat offspring
}

\author{
S.A. Farid ${ }^{1}$, O.M. Mahmoud ${ }^{1}$, N.A. Salem¹, G. Abdel-Alrahman'1, G.A. Hafez ${ }^{2}$ \\ ${ }^{1}$ Anatomy Department, Faculty of Medicine, Suez Canal University, Ismailia, Egypt \\ ${ }^{2}$ Pathology Department, Faculty of Medicine, Suez Canal University, Ismailia, Egypt
}

[Received 12 May 2015; Accepted 15 July 2015]

Poor nutrition of women during pregnancy causes reduction in foetal growth and can adversely affect the development of the foetal lungs. The purpose of the present study was to assess the effects of maternal protein restriction on the postnatal lung development in neonatal period, and on lung structure in adult rat offspring. Female virgin Sprague-Dawley albino rats (more than $200 \mathrm{~g}$ ) were used. One male rat was introduced into a cage with one female for matting. Once the pregnancy was confirmed, pregnant rats were divided into two main groups; each consists of 6 female as follow: 1 - normally nourished group; 2 - protein deficient group. After delivery, offspring were subdivided into three groups: 1 day after delivery, 2 weeks and 2 months postnatal. Rat body and lung weight were recorded and ratio of lung weight to body weight was assessed. Total plasma protein and serum albumin were assessed for all groups. Lung tissue stained with H\&E for histological and morphometric analysis. Immunohistochemistry was performed to evaluate the number of cells positive for pulmonary surfactant protein A. Our results showed that protein restriction interfere with neonatal and postnatal lung development resulting in morphological and morphometric changes of normal lung development. We concluded that protein deficiency lead to developmental retardation of lung. (Folia Morphol 2015; 74, 4: 479-485)

Key words: lung development, protein restriction, rat

\section{INTRODUCTION}

The respiratory failure caused by lung immaturity and dysplasia is still the most important factor leading to a high morbidity and mortality in the prenatal period [2]. Poor nutrition during pregnancy causes reduction in foetal growth and adversely affects the development of the foetal lungs [25].

Lung development commences in the embryo and continues postnatal [2]. During the alveolar stage in rat, cell proliferation and differentiation occur with proliferation of secondary alveolar septa. The alveolar type Il cells proliferate and produce surfactant on the alveolar surface [24]. Factors that interfere with the developmental program during any developmental phases may result in altered lung function and/or increased risk of diseases in later life [3]. Among these factors which affect lung maturation was maternal malnutrition especially protein restriction [18].

Although results from animal studies have shown that protein is important determinant factors for early lung development and size, data are lacking on the long-term consequences of maternal protein restric-

Address for correspondence: Dr O.M. Mahmoud, Anatomy Department, Faculty of Medicine, Suez Canal University, Zip code: 41111, Ismailia, Egypt, tel: 01272759000, e-mail: omima34@hotmail.com 
tion on lung health in human populations and on the structure of the lungs throughout postnatal life [9].

In vivo models of lung development, inflammation and infection are essential in the development of new directions for molecular approaches to understanding pathophysiology. The most models widely used were rats and mice, due to their ease of manipulation and low cost. Rodent models lend further support that they were of potential human health risk. Rat had similar response to inflammation and infection as human with players of proteins being often times similar [11]. So we used rat model in this work to determine the effects of maternal protein restriction on the postnatal lung development in rat offspring.

\section{MATERIALS AND METHODS}

Female virgin Sprague-Dawley albino rats (more than $200 \mathrm{~g}$ ) were obtained from the animal house of the Faculty of Veterinary Medicine, Suez Canal University (SCU). All animals were housed in environmentally controlled rooms, in wire cages at room temperature.

Ethical considerations. All animal experiments were carried out in accordance with the guidelines of Institutional Animals Ethics Committee of SCU.

Diet. Diet programs were prepared in Faculty of Veterinary Medicine in SCU as follow: 1 - normal diet containing $20 \%$ of proteins; 2 - protein deficient diet containing $6 \%$ of proteins. The diet started 7 weeks before mating then continued during gestation and lactation. This regimen gives long term consequences in rat [19].

Breeding. One male Sprague-Dawley albino rat was introduced into a cage with 1 female and remained there overnight. Early next morning pregnancy was determined by the presence of spermatozoa in the vaginal smears. This considered the first day of gestation.

Experimental design. There were two main groups; each group consists of 6 female albino rats as follow: (1) Normally nourished group (control); (2) Protein deficient group. After delivery, rat offspring of each main group were divided into three sub-groups, 1 day after delivery, 2 weeks postnatal and 2 months postnatal. Rat body weight and lung weight were recorded and the ratio of lung weight to body weight was assessed [23].

Haematological evaluation. Blood sample was collected after sacrificed the rat offspring using vacutainer tubes and ethylene-diamine tetra-acetate (EDTA) as an anti-coagulant [12]. Plasma was assessed for total plasma protein and serum albumin for all groups [7].

Histological evaluation. The trachea was cannulated and infused with $4 \%$ paraformaldehyde (PFA). The lungs were removed then immersed in 4\% PFA for $24 \mathrm{~h}$. Lung tissue was sectioned at $5 \mu \mathrm{m}, 10$ slides were stained with haematoxylin and eosin (H\&E) for histological and morphometric analysis.

Image morphometry. The morphometric analysis was performed at the Pathology Department, National Research Centre using the Leica Qwin 500 Image Analyser (LEICA Imaging Systems Ltd, Cambridge, England) which consists of Leica DM-LB microscope with JVC colour video camera. The following items were assessed:

- The mean number of alveoli: expressed in length units (number of alveoli/ $\mathrm{mm} \times 10^{3}$ ) [21].

- Alveolar surface area in $\mathrm{mm}^{2}$ : to evaluate maturation of internal surface area available for gas exchange [26].

- Thicknesses of alveolar septa: (random 50 septa per slide) expressed in $\mu \mathrm{m}$ [16].

Immunohistochemical staining. Anti-surfactant protein A (Precursor) Ab-1 (Clone SPA01; same as (1-2-A5- 9) mouse monoclonal antibody (from Lab Vision Corporation) was used to evaluate the number of cells positive for pulmonary surfactant protein $A$ (SP-A). The mean value of 10 fields in each rat was calculated at a magnification of $\times 400$ and the number of SP-A positive cells were expressed in $\mathrm{mm}^{2}$ [10].

Statistical analysis. ANOVA and post-hoc Tukey's HSD were used. Probability level of $p$ value $<0.05$ was considered statistically significant and $p$ value $<0.01$ was considered highly statistically significant.

\section{RESULTS}

\section{Day 1}

Body weight, lung weight and lung weight/ body weight ratio. All these parameter showed significant decrease in protein restricted group in comparison to control group.

Haematological values. Total plasma protein level $[\mathrm{mg} / \mathrm{dL}]$ and serum albumin level $[\mathrm{mg} / \mathrm{dL}]$ at day 1 showed significant decrease in protein restricted group in comparison to control group (Table 1).

Histopathological results. The lung was in the saccular stage. These saccules were irregular in shape and expanded with thin primitive septa and contained different types of cells such as lymphocytes and 
Table 1. Total plasma protein level and serum albumin level in all study groups

\begin{tabular}{lccccc}
\hline & \multicolumn{2}{c}{ Control groups } & & \multicolumn{2}{c}{ Protein restricted groups } \\
\cline { 2 - 3 } \cline { 5 - 6 } & Total protein level [mg/dL] & Albumin level [mg/dL] & & Total protein level [mg/dL] & Albumin level [mg/dL] \\
\hline Day 1 & $77.5 \pm 2.08$ & $4.4 \pm 1.9$ & & $58.2 \pm 1.7^{*}$ & $3.3 \pm 0.5^{*}$ \\
14 day & $79.2 \pm 2.9$ & $4.6 \pm 0.6$ & & $52.1 \pm 1.7^{*}$ & $2.8 \pm 0.08^{*}$ \\
2 months & $68.6 \pm 1.2$ & $3.6 \pm 0.5$ & & $40.8 \pm 2.02^{*}$ & $1.56 \pm 0.09^{*}$ \\
\hline
\end{tabular}

${ }^{*}$ ANOVA and Tukey's HSD tests: statistically significant $(p<0.05)$

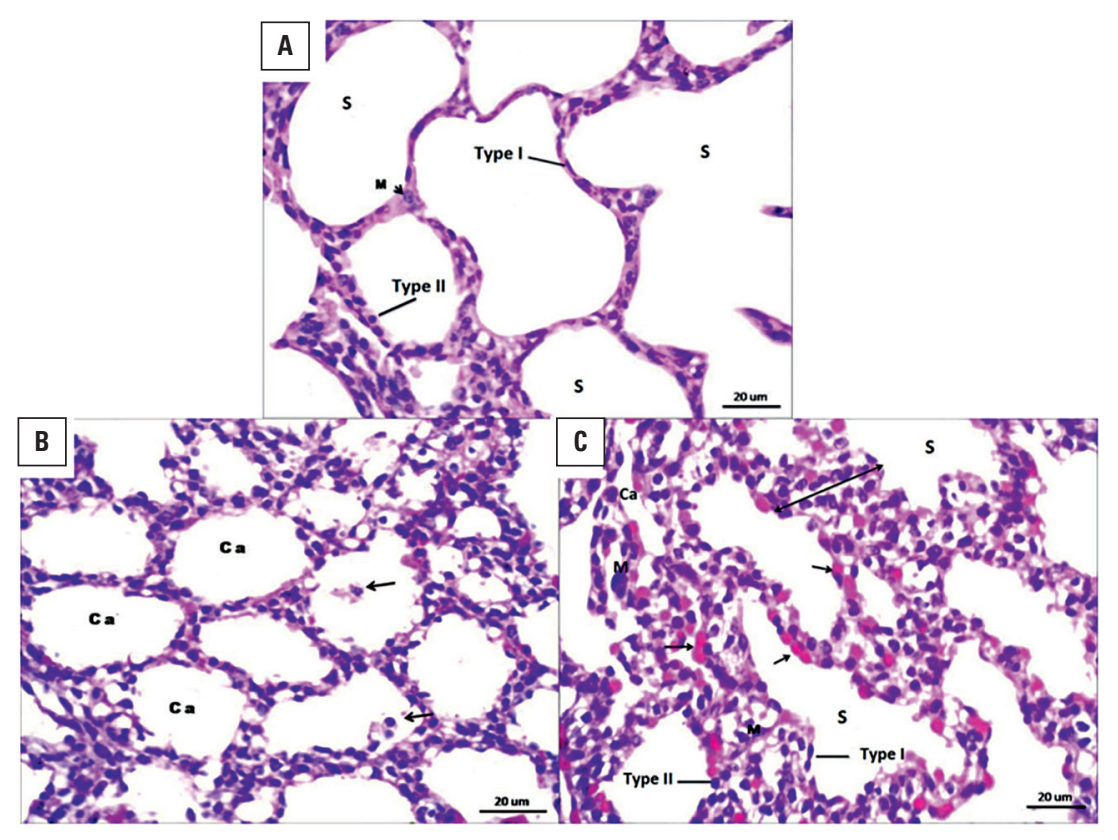

Figure 1. A photomicrograph of rat offspring lung at day 1 postnatal showing control (A) lung at the saccular stag (S). The primary septa lined by type I, type II pneumocytes and few macrophages (M); B. Protein restricted group lung at the canalicular stage (Ca), detached type II pneumocytes (arrows); C. Protein restricted group, thick saccular septa (two pointed arrow), many capillaries (arrows), and macrophages (M) $(H \& E \times 400)$. macrophages. Its free surfaces lined by type I and type II epithelial cells. Type I pneumocyte with flattened nuclei and attenuated cytoplasm. Type II pneumocyte had large deeply stained nuclei with abundant cytoplasm and looked cuboidal in shape in most regions. Bronchioles were lined by simple columnar ciliated epithelium. Each bronchiole was usually accompanied by branches from pulmonary artery and vein (Fig. 1).

The lung tissue in protein restricted group revealed different stages of development; some parts were in the saccular stage, other parts still in canalicular stages (acini lined by cuboidal epithelium with excess capillary networks). The saccular septa were thicker than control group with excess blood capillaries. Its free surfaces lined by less type I and type II pneumocytes (Fig. 1).

- Thickness of saccular septa $[\mu \mathrm{m}]$ : The mean septal thickness showed significant increase in protein restricted group in comparison to control group (Table 2).

- Alveolar number [per $\mathrm{mm}^{3}$ ]: The mean alveolar number showed significant decrease in protein restricted group in comparison to control group (Table 2).

- Internal surface area [ $\left.\mathrm{mm}^{2}\right]$ : There was significant decrease in the mean internal surface area between control group and protein restricted group (Table 2).

- Number of SP-A antibody positive cells [per $\mathrm{mm}^{2}$ ]: Counting the number of positively stained type II pneumocytes showed significant decrease in the protein restricted group comparison to control group (Fig. 4, Table 2).

Day 14

Body weight, lung weight and lung weight/ /body weight ratio. There was significant decrease in body weight and lung weight in protein restricted group in comparison to control group but there was insignificant difference of lung weight/body ratio in protein restricted group in comparison to control group.

Haematological values. Total plasma protein level $[\mathrm{mg} / \mathrm{dL}]$ and serum albumin level $[\mathrm{mg} / \mathrm{dL}]$ of rat pups 
Table 2. Mean thickness of alveolar septa $[\mu \mathrm{m}]$, alveolar number [per $\left.\mathrm{mm}^{3}\right]$, internal surface area $\left[\mathrm{mm}^{2}\right]$, length of elastic fibres $[\mu \mathrm{m}]$ and mean number of SP-A positive cells [per $\mathrm{mm}^{2}$ ] in all study groups

\begin{tabular}{|c|c|c|c|c|c|c|}
\hline \multirow[t]{2}{*}{ Groups } & \multicolumn{2}{|c|}{ Day 1} & \multicolumn{2}{|c|}{14 days } & \multicolumn{2}{|c|}{2 months } \\
\hline & $C(n=47)$ & $P(n=37)$ & $C(n=44)$ & $P(n=33)$ & $C(n=42)$ & $P(n=25)$ \\
\hline Thickness of alveolar septa $[\mu \mathrm{m}]$ & $12.64 \pm 0.36$ & $25.19 \pm 1.5^{*}$ & $5.78 \pm 0.9$ & $11.43 \pm 0.71^{*}$ & $3.81 \pm 0.92$ & $8.84 \pm 0.6^{*}$ \\
\hline Alveolar number [per mm³] & $28.2 \pm 2.4$ & $22 \pm 0.9^{*}$ & $48.8 \pm 3.2$ & $39.6 \pm 2.4^{*}$ & $83 \pm 3.8$ & $58.4 \pm 4.2^{*}$ \\
\hline Internal surface area $\left[\mathrm{mm}^{2}\right]$ & $199.39 \pm 14.84$ & $170.05 \pm 11.7^{*}$ & $282.35 \pm 17.72$ & $223 \pm 19.83^{*}$ & $314.65 \pm 17.23$ & $230.1 \pm 37.5^{*}$ \\
\hline SP-A positive cells [per mm²] & $83 \pm 13.9$ & $66.8 \pm 13.2^{*}$ & $268.8 \pm 23.2$ & $211.57 \pm 8.4^{*}$ & $828.2 \pm 42.4$ & $436.7 \pm 13.8^{*}$ \\
\hline
\end{tabular}

${ }^{*}$ ANOVA and Tukey's HSD tests: statistically significant $(p<0.05) ; C$ - control; $P$ - protein restricted groups; $n$ - number of offspring per group; SP-A - surfactant protein A antibody

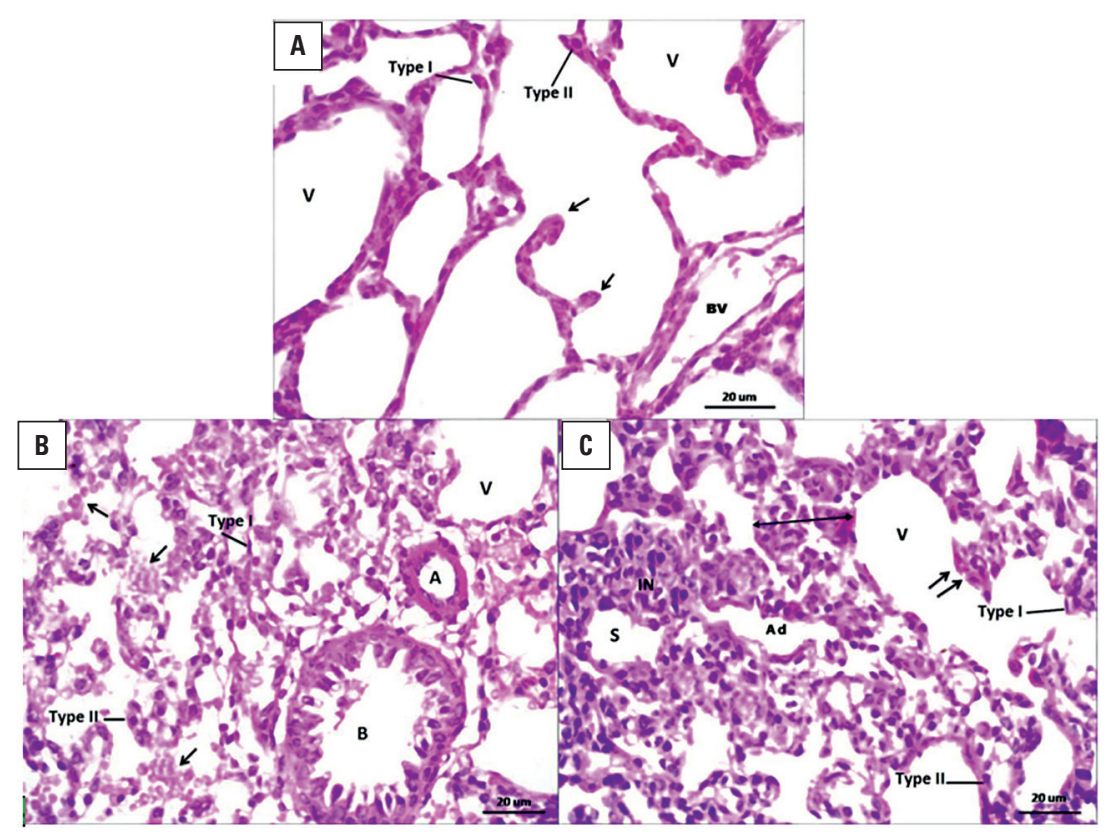

Figure 2. A photomicrograph of rat offspring lung at day 14 showing control (A) alveolar stage (V), primary septa lined by type I and type II pneumocytes, secondary septa (arrows) and blood vessel (BV); B. Protein restricted group, extravasated red blood cells (arrows) and bronchiole (B) with associated arteriole (A); C. Saccul (S), thick alveolar septa (two pointed arrow), inflammatory infiltrations (IN) and alveolar duct (Ad) (H\&E $\times 400)$.

showed a significant decrease in protein restricted group in comparison to control group (Table 1).

Histopathological results. The lung of control was in the alveolar stage and it looked like the adult lung. Alveoli were separated from each other's by alveolar septa which could be primary alveolar septa or secondary septa and its free surface was covered with type I and type II pneumocytes and containing only single capillary layer. Normal lung architecture and normally mature bronchioles, lined by ciliated columnar epithelium in larger bronchioles or non-ciliated epithelium in smaller ones and usually accompanied by a branch of the pulmonary vessel were noted (Fig. 2). In protein restricted group most of the lungs were in alveolar stage, but some areas were still in the saccular stage. The septa were thick and contain many capillaries with extravasated red blood cells inside alveoli. The secondary septa were few and thick and inflammatory infiltrations were noted (Fig. 2).

- Thickness of alveolar septa $[\mu \mathrm{m}]$ : The mean thickness of alveolar septa was significantly incre- ased in protein restricted group comparison to control group (Table 2).

- Alveolar number [per $\mathrm{mm}^{3}$ ]: The mean alveolar number showed significant decrease in protein restricted group in comparison to control group (Table 2).

- Internal surface area [ $\left.\mathrm{mm}^{2}\right]$ : The mean internal surface area showed significant decrease in protein restricted group in comparison to control group (Table 2).

- Number of SP-A antibody positive cells [per $\mathrm{mm}^{2}$ ]: The number of positively stained type II pneumocytes was significantly decreased in protein restricted group in comparison to control group (Fig. 4, Table 2).

\section{Two months}

Body weight, lung weight and lung weight/ /body weight ratio. The body weight and lung weight at 2 months showed significant decrease in protein 


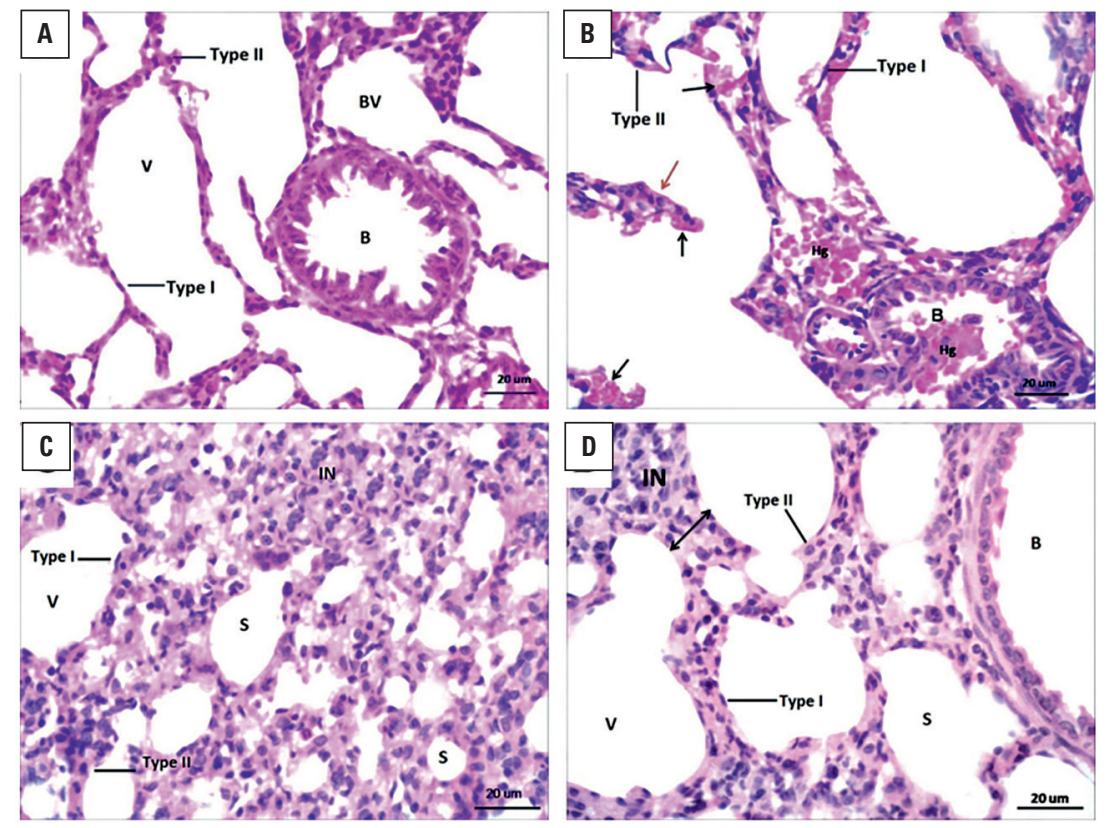

Figure 3. A photomicrograph of rat offspring lung at 2 months showing control (A) lung at alveolar stage (V), type I and type II pneumocytes, bronchiole (B) and blood vessel (BV); B. Protein restricted group, secondary septa (red arrow), interstitial haemorrhage (black arrows), intrabronchial haemorrhage $(\mathrm{Hg})$; C. Protein restricted group lung at saccular (S) alveolar stages (V), and inflammatory infiltrates (IN); D. Thick alveolar septa with increased cellularity (two pointed arrow) (H\&E $\times 400)$. restricted group but the lung weight to body weight ratio was increased in protein restricted group compared to control group.

Haematological values. Total plasma protein level [mg/dL] and serum albumin level $[\mathrm{mg} / \mathrm{dL}$ ] showed significant decrease in protein restricted group in comparison to control group (Table 1).

Histopathological results. The lung tissue of control group revealed that the lungs were in the alveolar stage. There were mature alveolar septa containing single capillary layer forming an extensive plexus around each alveolus. Normal lung architecture and normally mature bronchioles accompanied by a branch of the pulmonary vessel were noted (Fig. 3). In protein restricted group, the lung development was in alveolar stage, but some parts were still in saccular stage; some alveoli showed inflammatory infiltrations. The alveolar septa were thick and lined by both type I and II pneumocytes. The septa showed increase cellularity and capillaries with extravasated red cells in interstitial tissues and in intra-alveolar sacs, congested and dilated blood capillaries were noted (Fig. 3).

- Thickness of alveolar septa $[\mu \mathrm{m}]$ : The mean thickness of alveolar septa showed significant increase in protein restricted group in comparison to control group (Table 2).

- Alveolar number [per $\mathrm{mm}^{3}$ ]: The mean alveolar number showed significant decrease in protein restricted group compared to control group (Table 2).
- Internal surface area [ $\left.\mathrm{mm}^{2}\right]$ : The mean of internal surface area showed significant decrease in protein restricted group versus to control group (Table 2).

- Number of SP-A antibody positive cells [per $\mathrm{mm}^{2}$ ]: The mean number of positively stained type II pneumocyte showed significant decrease in protein restricted group in comparison to control group (Fig. 4, Table 2).

\section{DISCUSSION}

Nutritional deficiencies either prenatal or postnatal in experimental animals have been associated with structural alterations of the lung development, injury and repair [20].

Control group of this study showed gradual increase in body weight, lung weight and lung weight/ body weight ratio from day 1, day 14 till 2 months, which was in agreement with the data reported by Buri et al., 1974 [2] who assessed normal lung growth and differentiation. All of the histological results of control group at different ages in the present study agreed with those resulted from many researchers $[13,24]$. Regarding the morphometric measures of the septal thickness, our results agreed with other studies [1] which reported that in the developing lung there was not only formation of new septa but also lengthening and thinning of septa achieved by stretching and redistribution of the tissue mass. The mean alveolar number in this study was significantly increased in control group from day 1 until 2 months which matched with many researches [21]. In the 


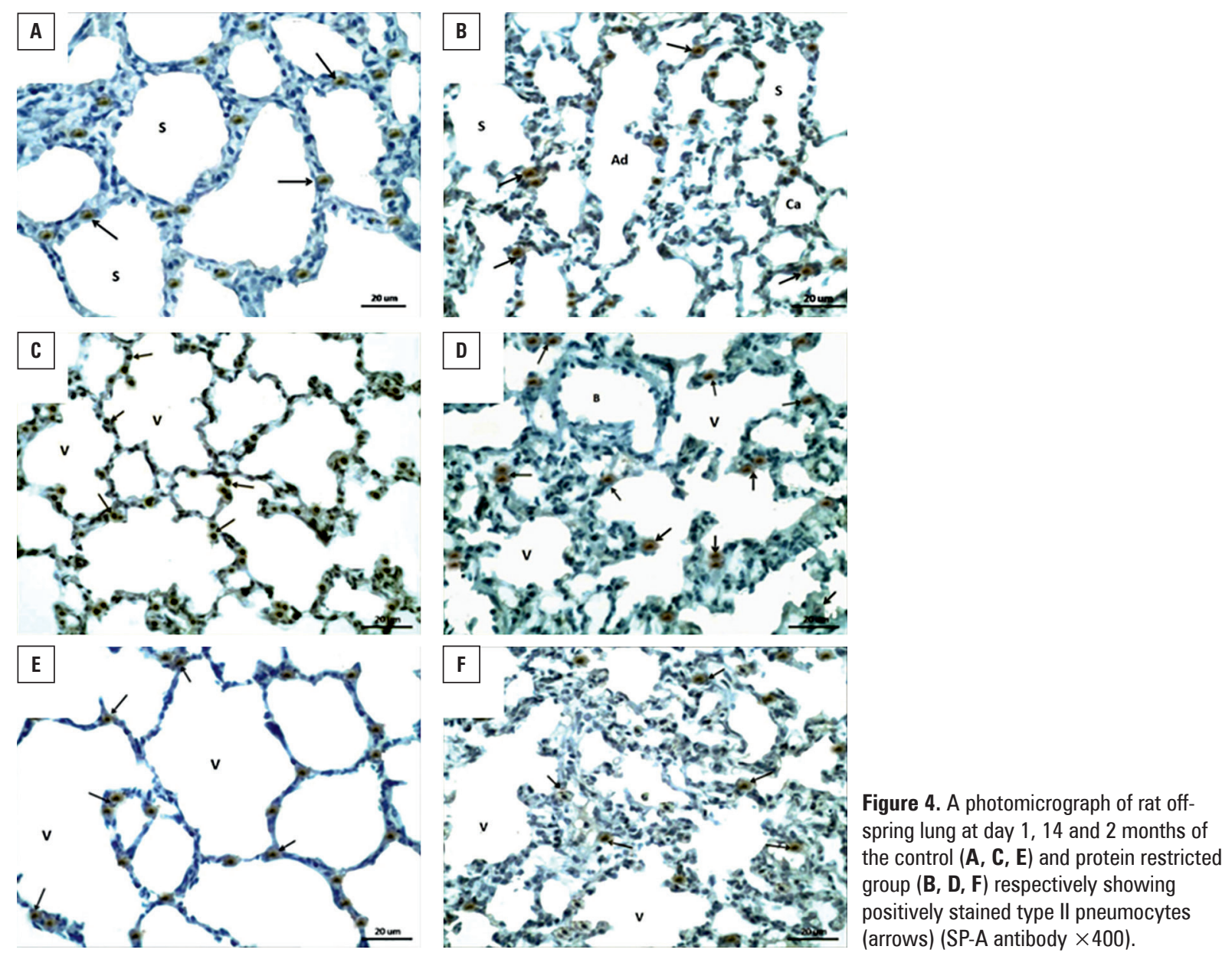

present study, the mean internal surface area was significantly increased gradually in control group from day 1 until 2 months, in keeping with many studies done by other researchers [8].

Surfactant protein-A (SP-A) is the most prevalent protein component of pulmonary surfactant, produced by mature alveolar type II pneumocytes for maintaining alveolar stability. In rat positively stained cells began in canalicular stage then gradually increased to be completed in adult stage [15].

Similar findings of the body weight, lung weight and lung weight to body weight ratio in protein restricted group were mentioned by other studies $[14,17]$. The decrease in body weight, lung weight and lung weight to body weight ratio at day 1 and 14 may be due to decrease in the amount of protein content in the body and organs which was essential component of tissue elements, but the increased lung weight to body weight ratio at 2 months may be due to decrease in lung weight more than body weight or increase in the body weight which caused by fluid retention resulted from hypo-albuminaemia.
Results of the haematological values of protein restricted group agreed with other study [27]. Regarding histological findings, delayed lung development in protein restricted group was noticed in comparison to control group; similar findings were reported by Winick et al. [29] who studied cellular responses in rat lung with malnutrition at various ages.

More development of alveoli was noticed at 2 months of protein restricted group. These findings coincide with results done by Das [4] and Dias et al. [6] who studied the effects of intermittent protein starvation on lung development.

Prolonged protein deficiency from prenatal to postnatal period leads to decrease in alveologenesis through decreasing the cell division, proteins and amino acids essential for complete alveolar formation, decrease in elastin and collagen deposition. Therefore a reduction in these deposits could interfere with alveolar septation, causing arrest in alveolar development and increase septal thickness. Inflammatory cells infiltration in the lung denotes susceptibility of the lung to infection by decreasing the lung host defence mechanisms caused by protein restriction. 
The morphometry of septal thickness of protein restricted group showed significant increase in all age groups in comparison to control group. These findings agreed with Dias et al. [5]. There was significant decrease in the mean alveolar number in protein restricted group in all age groups in comparison to control group, these findings were agreed with Knust et al. [16]. The mean internal surface area of protein restricted group showed significant decrease in all age groups in comparison to control group. The same findings were reported by Ohashi et al. [22], this decrease may be due to prolonged protein deficiency leading to decrease in synthesis of specific proteins, growth factors and amino acids essential for organ growth and differentiation leading to delayed alveolar formation, irreversible damage of air spaces due to decrease production of connective tissue and disruption of pulmonary architecture.

The number of positively stained type II pneumocytes by anti-surfactant protein-A in protein restricted group showed significant decrease in all age groups in comparison to control group, these were similar to results obtained by other study [28]. These may be due to reduction of essential protein for surfactant production and metabolism.

\section{CONCLUSIONS}

Finally, it could be concluded that maternal and postnatal protein restriction interfere with neonatal and adult lung development resulting in changes in morphologic and morphometric characteristics of the normal alveolar maturation, alveolar septa and lung parenchyma, which make the lung more susceptible to many respiratory diseases.

\section{REFERENCES}

1. Burri PH (1974) The postnatal growth of the rat lung. III morphology. Anat Rec, 180: 77-98.

2. Burri PH, Dbaly J, Weible ER (1974) The postnatal growth of the rat lung. I morphometery. Anat Rec, 178: 711-730.

3. Cardoso WV, Lue J (2006) Regulation of early lung morphogenesis. Questions, facts and controversies. Development, 133: $1611-1624$

4. Das RM (1984) The effects of intermittent starvation on lung development in suckling rats. Am J Pathol, 117: 326-332.

5. Dias CM, Passaro CP, Antunes MA, Cagido VR, Einicker-Lamas M, Lowe J, Negri EM (2008) Effects of different nutritional support on lung mechanics and remodeling in undernourished rats Respiratory. Physiol Neurobiol, 160: 54-64.

6. Dias CM, Pássaro CP, Cagido VR, Einicker-Lamas M, Lowe J, Negri EM, Capelozzi VL, Zin WA, Rocco PR (2004) Effects of undernutrition on respiratory mechanics and lung parenchyma remodeling. J Appl Physiol, 1888-1896.
7. Doumas W, Watson G, Biggs H (1971) Albumin standards and the measurement of serum albumin with bromcresol green. Clin Chim Acta, 31: 87-96.

8. Dunnill M S (1962) Quantitative methods in the study of pulmonary pathology. Thorax, 17: 320-328.

9. Foula Sozo C, Richard Harding K, Jane Black H (2011) Lung Development in rats after maternal protein restriction during pregnancy: long term effects. Principle Research Fellow. Am Emberyol, 117: 326-332.

10. Han XN, Ruan YM, Zhang XC, Wang HY, Chu Y (2000) Changes of surfactant $A$ and $B$ in alveolar type cells in hamster with elastase-induced emphysema. Chin J Pathol, 29: 43-45.

11. Hoenerhoff $M$ J, Hong HH, Ton TV, Lahousse SA, Sills RC (2009) A review of the molecular mechanisms of chemically induced neoplasia in rat and mouse models in National Toxicology Program bioassays and their relevance to human cancer. Toxicol Pathol, 37: 835-848.

12. Hulmes JD, Betheab D, Ho K, Huang SP, Ricci DL (2004) An investigation of plasma collection, stabilization, and storage procedures for proteomic analysis of clinical samples. Clin Proteomics J, 1: 17-31.

13. Jesudason $F(2005)$ Normal morphometry of lung development in rats. Res Med, 3: 54-57.

14. Kalenga M, Tschanz SA, Burri PH (1995) Protein deficiency and the growing rat lung. Pediatric Res, 37: 789-795.

15. Khubchandani R, Snyder JM (2001) Surfactant protein A (SP-A): the alveolus and beyond. FASEB J, 15: 59-69.

16. Knust J1, Ochs M, Gundersen HJ, Nyengaard JR (2009) Stereological estimates of alveolar number and size and capillary length and surface area in mice lungs. Anat Rec, 292: 113-122.

17. Mataloun M, Leone R S, Mascaretti M, Dohlnikoff C, Rebello CM (2009) Effect of postnatal malnutrition on hyperoxia-induced newborn lung development. Braz J Med Biol Res, 42: 606-613.

18. Moretto VL, Ballen MO, Gonçalves TS, Kawashita NH, Stoppiglia LF, Veloso RV, Latorraca MQ, Martins MS, Gomes-da-Silva MH VL, Ballen MO, Gonçalves TS, Kawashita NH, Stoppiglia LF, Veloso RV, Latorraca MQ, Martins MS, Gomes-da-Silva MH (2011) Low-protein diet during lactation and maternal metabolism in rats. J Obs Gyn, 22: 55-60.

19. Mulchand SP, Malathi D (2004) Metabolic programming: long consequences of maternal high carbohydrate feeding on postnatal period of rats offspring. Neo Rev, 5: $12-16$.

20. Newnham JP, Ross MG (2009) Early life origins of human health and disease. Basel Karger, 78-88.

21. Ochs $M$, Nyengaard JR, Jung $A$, Knudsen $L$, Voigt $M$, Wahlers T, Richter J, Gundersen HJG (2004) The number of alveoli in the human lung. Am J Respir Crit Care Med, 169: 120-124.

22. Ohashi T, Pinkerton K, Ikegami M, Jobe AH (1994) Changes in alveolar surface area, surfactant protein $A$, and saturated phosphatidylcholine with starved postnatal rat lung growth. Pediatr Res, 35: 685-689.

23. Scherle W (1970) Simple method for volumetry of organs in quantitative stereology. Microscopie, 26: 57-60.

24. Schittny JC, Schittny T, Burri PH (2007) Development and Growth of the Lung. Am Rev Respir Dis, 129: 607-613.

25. Shi W, Bellusci S, Warburton D (2007) Lung development and adult lung diseases. Chest, 132: 651-6102.

26. Thurlbeck WM (1967) Internal surface area and other measurements in emphysema. Thorax, 22: 483-496.

27. Von A, Carpentier R, Barthe J, Bruyns J (2002) Plasma protein concentration in nutritional, assessment remodeling. J Appl Physiol, 1888-1896.

28. Weaver TE, Khoor A Whitsett JA (1991) Function and regulation of expression of pulmonary surfactant-associated proteins and protein deficiency. Biochem J, 273: 249-264.

29. Winick M, Rucker RB, Noble A (1966) Cellular responses in rats during malnutrition at various ages. J Nutrit, 89: 300-306. 